\title{
The Contribution of Modern Market to The Economic Growth of Poso Regency (The Case Study of Poso City Mall Modern Market)
}

\author{
Syahruddin Hattab ${ }^{1}$, Mahpuddin ${ }^{2}$, Daswati $^{3}$ \\ \{udinhattab60@gmail.com ${ }^{1}$, mahpuddin_untad@yahoo.co.id ${ }^{2}$, daswatisahar@gmail.com ${ }^{3}$ \} \\ Department of Public Administration, Faculty of Social and Political Sciences, Tadulako University, \\ Palu, Indonesia ${ }^{1,3}$, Department of Communication Studies, Faculty of Social and Political Sciences, \\ Tadulako University, Palu, Indonesia ${ }^{2}$
}

\begin{abstract}
The economic growth of the Poso Regency has been relatively stable in the past few years. There is a paradoxical indication that the amount of regional revenue and public service infrastructure construction has increased every year. Yet, it is not equal to the acceleration of micro-economic businesses' growth. On the other hand, poverty and unemployment rates are still relatively high which triggered various speculations, one of them directed to large-scale investors such as the existence of modern markets. Poso City Mall (PCM) is the largest modern shopping centre in Poso Regency which is considered by some as a reliable competitor that creates an imbalance climate in business competition. This research carried out using a descriptive-qualitative approach. The collected research data was mostly derived from institutional data combined with the results of in-depth interviews. The data validity is triangulated and tested through Focused Group Discussion (FGD) and interpreted in an interpretative way. The results showed that the existence of Poso City Mall (PCM) had a positive contribution in terms of (1) regional revenue through the tax; (2) encouraging the growth of community economic businesses; (3) policy priority for local workers recruitment. But, the nonoptimal condition of PCM internal management combined with an external economic situation caused stagnation and even an alarming indication of the business crisis. In addition, the Poso Regional Government's commitment and support were not enough in overcoming the threat of the crisis.
\end{abstract}

Keywords: Contribution, Modern Markets, Economic Growth

\section{Introduction}

Trade centre is an important aspect of the economy of a region. Based on its physical form, a trading centre is commonly referred to as a potential market place for certain bargains affected by all buyers [1]. The market plays an active role in economic development, especially in providing goods and services to fulfil community needs.

In the globalization era, the market function underwent many changes, not only guaranteeing the availability of goods but also having a strategic role in the economy [2]. Judging from the management characteristics, there are two market categories: traditional markets and modern markets. Modern Market is a market managed with modern management, generally located in the city, act as a good quality goods provider and service to upper and 
middle-class consumers. Modern markets include malls, supermarkets, department stores, shopping centres, franchises, convenience stores and so on [3].

In Indonesia, local supermarkets have existed since the 1970s, although still concentrated in big cities. Foreign branded supermarkets began to enter Indonesia in the late 1990s since foreign direct investment policies in the retail business sector opened in 1998. Increased competition has led to the emergence of supermarkets in small cities to find new customers and wage a price war. As a result, while Indonesian supermarkets only served the middleupper class community in the 1980s to early 1990s [4], the spread of supermarkets to small cities and price-cutting strategies allows lower-middle-class consumers to access supermarkets [5].

Poso Regency is one of the regions in Central Sulawesi province which is in the development stage after going through a terrible conflict [6]. The economic development efforts made by the regional government realized through cooperation with investors, especially those engaged in the development of modern shopping centres such as malls, supermarkets, department stores, shopping centres, franchises, convenience stores and so on [7]. Based on the pre-observations results, it is estimated that there are thousands of modern shopping places spread in Poso. In general, it appears that investments are a positive indication of the economic growth of the Poso Regency.

Poso City Mall (PCM) is a type of modern market that marks the beginning of a large influx of investment in Central Sulawesi. The realization of the PCM development raised new hopes that encourage the economic growth of Poso. PCM is expected to trigger economic movements, opening new jobs, and the availability of products needed by the community. There are important indicators to see the characteristics of economic growth in an area, such as an increase in regional real estate, an increase in welfare, employment opening accompanied by a decrease in poverty.

The presence of modern markets aroused various speculations about fears of creating inequality in business competition and its particular impact on MSMEs. Modern markets such as PCM are a source of anxiety that will weaken and even turn off micro-businesses that are not located around the mall. In other words, the existence of a modern market does not always have a positive impact.

\section{Research Method}

This study is carried out using a descriptive-qualitative method [8], [9]. The main objective of this study is to examine in depth the phenomena of the modern market contribution to the economic growth development of Poso. This study was conducted within approximately three months (from early May to late July of 2019) in Poso Regency, Central Sulawesi Province, Indonesia. There are four techniques in total for data collection [10], [11], namely:

1. In-depth interviews with six informants: (1) The Head of Regional Office for Industries, Trades and Cooperatives of Poso; (2) A staff of the Regional Research and Development Office of Poso; (3) the Secretary of Regional Revenue Office; (4) One traditional market trader representative; (5) One Micro Business Entrepreneur representative; and (6) A PCM management representative.

2. Document study related to the collection of quantitative data on economic growth rates. In addition, local tax revenue data were also obtained from local government agencies. 
3. Field observations carried out to confirm and confront the data obtained through other data collection techniques.

4. Focused Group Discussion (FGD). There are two objectives for the use of data collection techniques through FGD: (a) comprehensive data clarification and validation; (b) completing and exploring data quality. There are 23 participants in total which consisted of three local government officials (The Head of Regional Office for Industries, Trades, and Cooperatives of Poso, staff of the Regional Research and Development Office of Poso, the Secretary of Regional Revenue Office), PCM management representatives, traditional market traders, and Micro Business Entrepreneurs.

Collected data were triangulated to proof and validify the accuracy of the data. The validated data were categorized into two main categories of this study (the contribution to Poso's economic growth and the downtrend) in which further classified and separated into specific aspects (the contribution to regional revenue, employment rate and community welfare; and visitor downtrend of PCM) to be interpreted, described and explained. Based on the data interpretation, a conclusion is drawn.

\section{Result and Discussion}

\subsection{The Modern Markets Contribution to Poso's Economic Growth}

Theoretically, the main indicators of economic growth of a country or region can be measured from 4 things: (1) National/regional real income; (2) real per capita income; (3) Population welfare and (4) Labor and unemployment rate. There are important indicators that can be used to analyze the contribution of modern markets to economic growth, namely regional real income obtained through the realization of revenue from the tax, contribution to the growth of micro-businesses and employment rate.

\subsubsection{The Contribution to the Regional Revenue}

The tax revenue amount is one important indicator to measure the level of economic growth in a region. When the economic condition of the community improved, it will have direct implications on the increase in local tax revenue. Circularly, the condition of the tax revenue will later determine the amount of funding for regional development programs that include the provision of public infrastructure and human resource capacity development in the region.

Poso City Mall (PCM) is the largest modern market in Poso Regency. Based on the results of scientific research, it was found that the presence of PCM has a relatively large contribution to regional income, especially from the tax revenue by $35 \%$ of the total tax revenue of the Poso Regency [12]. 


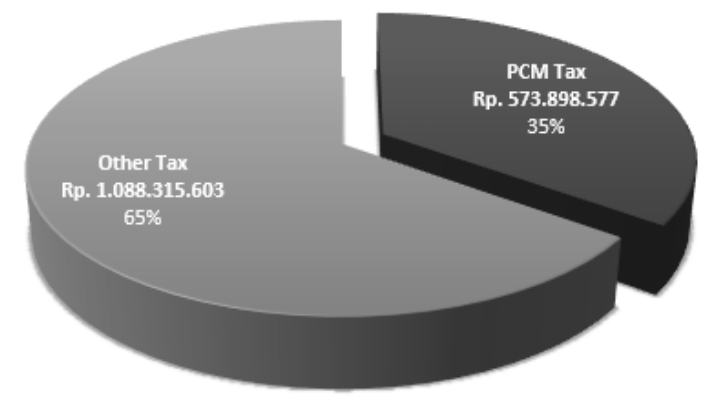

Fig. 1. Poso City Mall Tax Contribution of 2017 (Processed data)

The large amounts above are broken down into four business tax unit categories managed by PCM:

a. Entertainment tax revenue. PCM provided the largest tax contribution of 2018, amounting to RP. 211.289 .257 or $99 \%$. The form of entertainment offered by PCM is a children's playground.

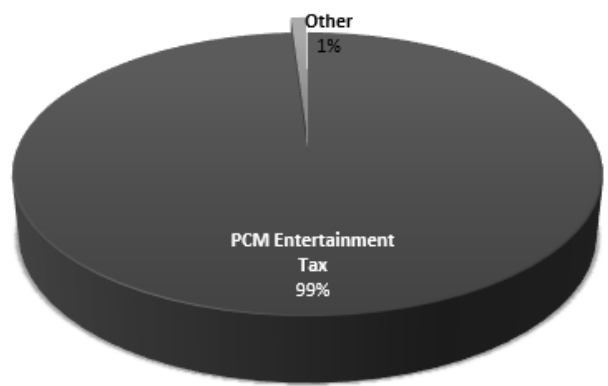

Fig. 2. Poso City Mall Entertainment Tax Contribution of 2017 (Processed data)

b. Parking tax revenue. PCM contributed RP. 65.55 .800 or around $99 \%$ of the annual parking tax obtained by the Regional Government of Poso Regency. Only 1\% of the parking tax is obtained from the taxpayer levy from other sources. Thus, revenue from entertainment and parking taxes in the Poso district government in 2018 was almost entirely obtained from PCM. An indication that strengthens the important position of PCM compared to other taxpayer businesses. 


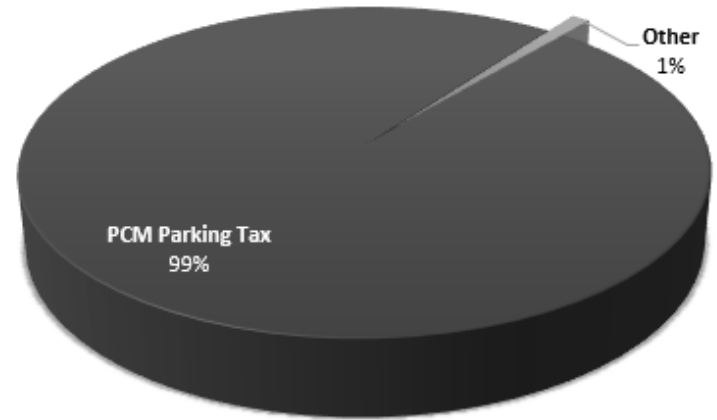

Fig. 3. Poso City Mall Parking Tax Contribution of 2017 (Processed data)

c. Restaurant tax revenue. PCM provides the largest contribution to the acquisition of local tax revenue, RP. 290.938 .972 or around $22 \%$ of all restaurant taxes obtained by the Poso Regency Government.

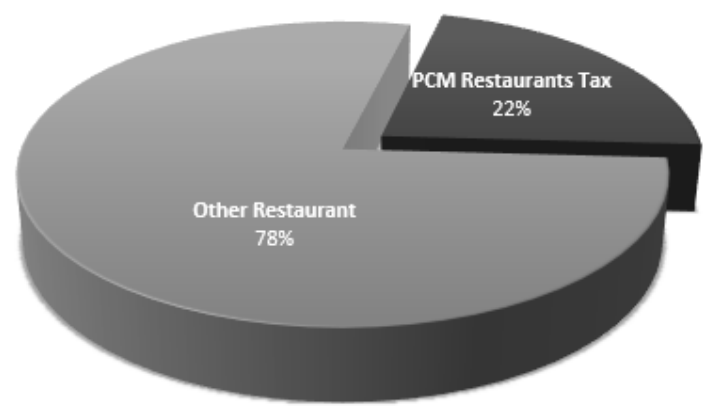

Fig. 4. Poso City Mall Parking Restaurant Tax Contribution of 2017 (Processed data)

d. Utility tax. PCM contributed RP. 3.647 .640 or around $58 \%$ of the annual total water tax obtained by the Poso District Government.

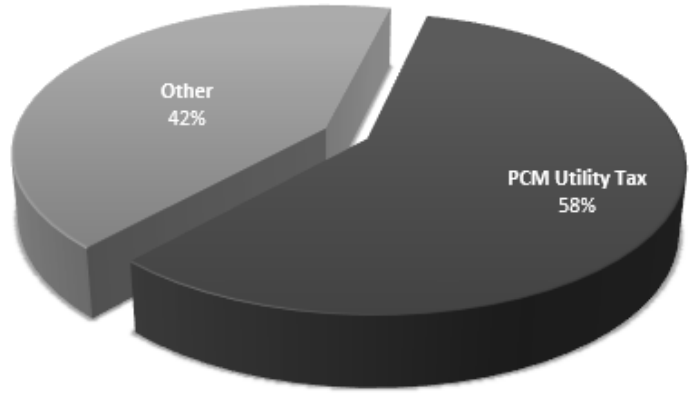

Fig. 5. Poso City Mall Utility Tax Contribution of 2017 (Processed data) 


\subsubsection{Contributions to Employment Rate}

Since 2016 which marked the operational sales activities, PCM has recruited hundreds of workers with a high priority on the local job seekers. No less than 600 workers were employed by PCM who almost all were citizens of Poso District.

According to PCM management, the policy is a form of PCM's commitment and effort to reduce the unemployment rate which naturally experiences an annual increase "trend" of job seekers. Out of the absorbed total workforce, most occupy sales positions who serve [12]prospective buyers. Other work such as freight transport personnel, technicians, cleaning service personnel, security guard personnel, and parking personnel.

As the visitors' downtrend happened, management forced to rationalize the budget and financing by laying off some workers. Based on the results of an internal analysis since 2017, 350 sales workers are laid off resulting in just around 250 left. It is also not optimally employed.

\subsubsection{Contribution to Community Welfare}

The existence of Poso City Mall (PCM) has an important role to encourage the economic development efforts of local communities. Since it officially began operating in 2016, together with MSMEs facilitated by the Regional Office for Industries, Trade, and Cooperatives of Poso, PCM has been collaborating in selling local products. The cooperation is in the form of providing rental outlets or relatively inexpensive places for micro-businesses to sell their products.

In the beginning, the collaboration between PCM and micro-business units had encouraged and inspired local traders to develop their businesses. With high enthusiasm, the merchants sold their products at PCM. Some traders occupy booths set up inside the building, others take place around the sidewalks and PCM entrances. These lively conditions lasted within a few months. By various factors, the situation has changed starting with the downtrend of prospective buyers visiting the mall.

The aforementioned condition proved that the existence of the modern market was not a serious threat to the development of micro-business of Poso Regency which instead became a positive business partner to stimulate the growth of local creative industries and micro business. The idea of the death of traditional markets based on the inability to compete with the growing modern markets [13] which became popular as of late was not evident in this case. The existence of micro-businesses and traditional markets is still prevalent.

Traditional markets and micro businesses of Poso not only sold more varied and relatively cheap products but also spread out as far as more than ten kilometres from PCM. The above one kilometre average of spacing created a healthy competition. This condition even made a worry of visitor downtrend to PCM.

\subsection{Visitor Downtrend Problem of PCM}

Since its initial operation in 2016, the number of visits to PCM is relatively high. The enthusiasm of the people visiting PCM was very encouraging as it was not limited to Poso but for the surrounding areas as well. But after a few months later, the number of visits experienced a downward trend up until this research was completed.

Hypothetically, it was predicted that if these conditions were not immediately addressed, then in the next few years, PCM as the pride of the Poso Regency would experience a severe crisis. This is an unfavourable business situation, both for the manager and the owner of the 
PCM capital, employees and the local government as the recipient of the tax. In comparison, the continued decline in profits is reflected in the significant decrease in taxpayer submissions made by PCM in the last 2 years.

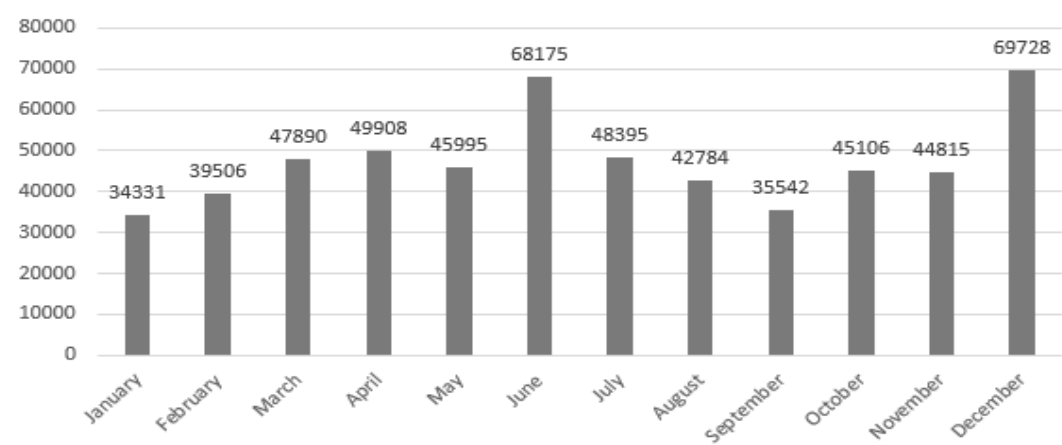

Fig. 6. Poso City Mall Visitors in 2017

Based on the infographic above, the number of PCM visitors on average is at 4.500 to 5.000 people (adult category) from January to December 2017. In June there was a significant surge in visitors to nearly seventy thousand visitors. This significant increase occurred just before Eid. In December there were 69.721 visitors.

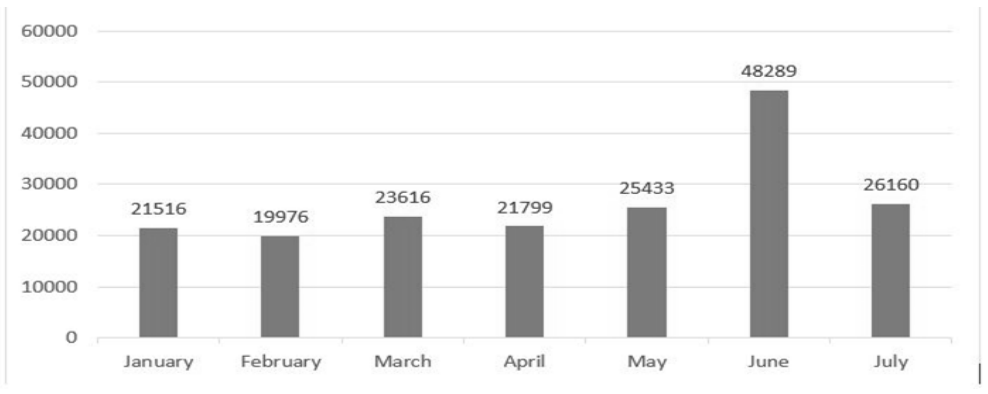

Fig. 7. Poso City Mall Visitors in January-July 2018

The infographic shows that from January to July 2018 the number of PCM visitors was in the average of 2.000 to 2.500 people (adult category). In June there was a significant surge in visitors, which was a $100 \%$ increase in the monthly average visitor.

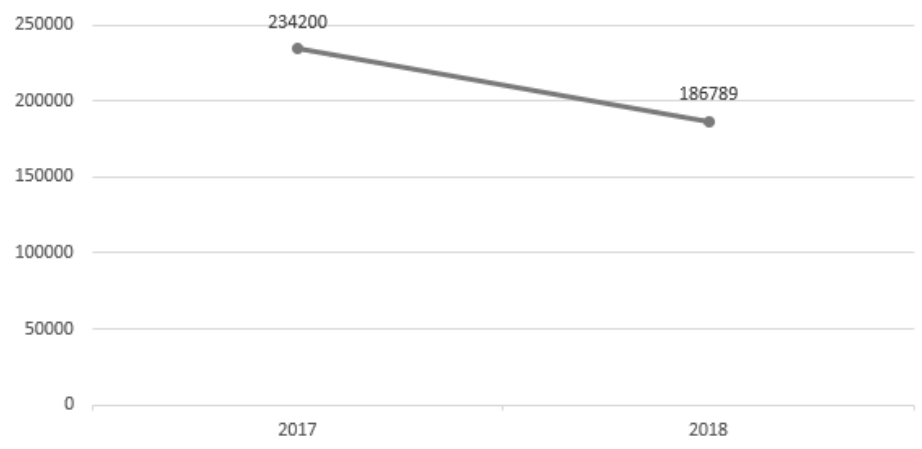


Fig. 8. Poso City Mall Visitors Trend from 2017 to 2018

Figure 9 shows a downtrend in the number of visitors. The downtrend is shown from the total 334.200 PCM visitors (January - July) in 2017 to 186.789 visitors in 2018 in the same month. The visitors' downtrend approached the $100 \%$ number.

The decrease in the number of visits has a multiplier effect which not only results in a decrease in business revenues but also tax obligations to local governments. The decrease in the amount of PCM income is reflected in the magnitude of taxpayers in the following charts:
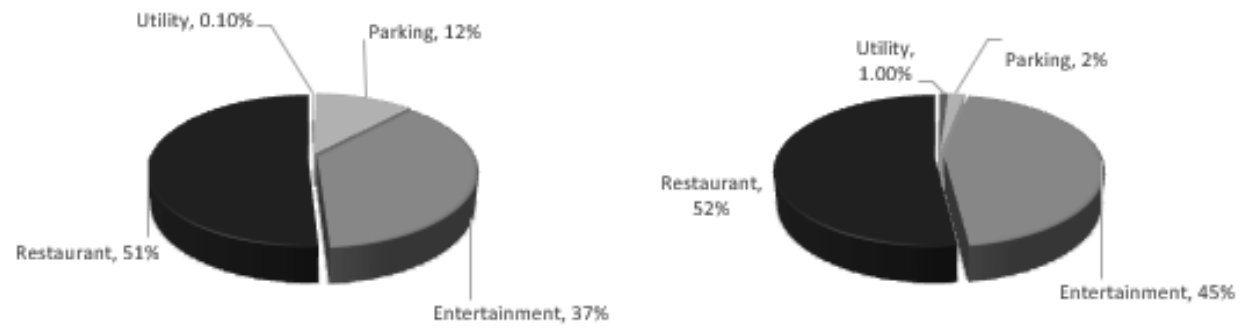

Fig. 9. Poso City Mall's Tax Revenue Comparison of 2017 and 2018

In addition to a direct impact on the decline in regional income from the tax revenue, the surge in the number of visitors also affected the rationalization policy for PCM operational financing or the efficiency of corporate spending. The intended form of efficiency includes streamlining the number of workers, which means termination of employment in large numbers. The PCM internal policy increases the number of unemployment rate in Poso. Based on the in-depth studies results, there were strong indications that were identified as the main problem (threat condition) causing the decline in the number of PCM visits, among others;

First, the rise of online businesses accessible from communication media, such as mobile phones, as a new model of business competition. The use of these communication tools has targeted potential customers with various promising customer services.

There are advantages of online business compared to conventional marketing models, among others:

(1) Prospective consumers only need to order products through the internet or mobile phone. Within a short time, the purchased product will be delivered to the prospective customer. This transaction mode has saved consumers' cost, time and energy. Price-sensitive consumers also consider choosing to buy products through this online system.

(2) Product prices offered by marketers via online networks are competitive. It is common to find similar products that are cheaper than the product offered on PCM. This happened because the cost of shipping is a conversion from tax-free obligation. Thus, the selling price of the product is relatively cheap or competitive.

(3) Varied types of products place online businesses as competitors that cannot be underestimated. Even in the last two years, online businesses have successfully targeted a broad range of consumers in the downtown area to the outskirts of Poso.

Secondly, a new type of market has emerged in Poso City which local people call the "illegal market." The market is crowded with buyers and operates 24 hours a day. Unclear regional government policies regarding the presence of these types of markets have triggered unfair business competition. Many criticisms were addressed to the regional government regarding this problem, but the regional government inconsistency responded. For 
humanitarian reasons, such as difficult employment conditions, the government is placed in a dilemmatic position to enforce the law.

Third, there appears to be an increase in the number of manufacturing products sales businesses that sprung up around Poso City, such as the construction of shops, minimarkets, convenience stores, kiosks, and traditional markets. The increasing number of sales businesses with similar product categories places PCM in the threat of visitors decrease every day.

\section{Conclusion}

Poso City Mall (PCM) has a positive contribution to the economic movement, including tax and retribution revenue, investment and large amounts of money flow, local labour absorption, MSME growth stimulation, increasing household product availability for the wider community and at the same time become an investment icon. Since 2016, these positive contributions have slowly declined over the past two years.

It is indicated that PCM experiences symptoms of stagnation and even the threat of crisis. In addition to the weakness of the PCM internal management system and the weak real support from the Regional government of Poso, the unconducive external environment changes also impact the prospective business growth.

\section{References}

[1] Kotler, P. and Keller, K. L. : Manajemen Pemasaran. (Jakarta: PT. Indeks) (2008)

[2] Kotler, P. and Keller, K. L. : Manajemen Pemasaran Jilid 2. (Jakarta: PT. Indeks) (2007)

[3] Sinaga, P. : Pasar Modern VS Pasar Tradisional, Jakarta. (2004)

[4] Jusmaliani. : Pembangunan Ekonomi Berkeadilan. (Jakarta: LIPI) (2008)

[5] Suryadarma. : Laporan Penelitian Dampak Supermarket terhadap Pasar dan Pedagang Ritel Tradisional di Pusat-pusat Perkotaan di Indonesia, Jakarta. (2007)

[6] Lasahido, T. : Suara Dari Poso Kerusuhan, Konflik, dan Resolusi. (Jakarta: YAPPIKA) (2003)

[7] Mahpuddin, I. Lampe, S. Zainuddin, M. Ramah, and I. Suryadi. : The Marginalization Of Street Vendors (Pkl) Amidst The Realization of Modern Market Development. Asian J. Environ. Hist. Herit., Vol 2. pp. 309-320 (2018)

[8] Bungin, B. : Teknik-Teknik Analisis Kualitatif dalam Penelitian Sosial. (Jakarta: Raja Grafindo Persada) (2003)

[9] Yusuf, A. M. : Metode Penelitian Kuantitatif, Kualitatif \& Penelitian Gabungan. (Jakarta: Kencana) (2014)

[10] Bungin, B. : Analisis Data Penelitian Kualitatif. (Jakarta: Rajawali Press) (2003)

[11] Sugiyono. : Metode Penelitian Kuantitatif, Kualitatif, dan R\&D. (Bandung: Alfabeta) (2013)

[12] Badan Pusat Statistik Poso. : Kabupaten Poso Dalam Angka, Poso. (2018)

[13] Malano, H. : Selamatkan Pasar Tradisional. (Jakarta: Gramedia Pustaka Utama) (2011) 